Kauffman Foundation Research Series on City, Metro, and Regional Entrepreneurship

\title{
Enabling Entrepreneurial Ecosystems
}

INSIGHTS FROM ECOLOGY TO INFORM EFFECTIVE ENTREPRENEURSHIP POLICY
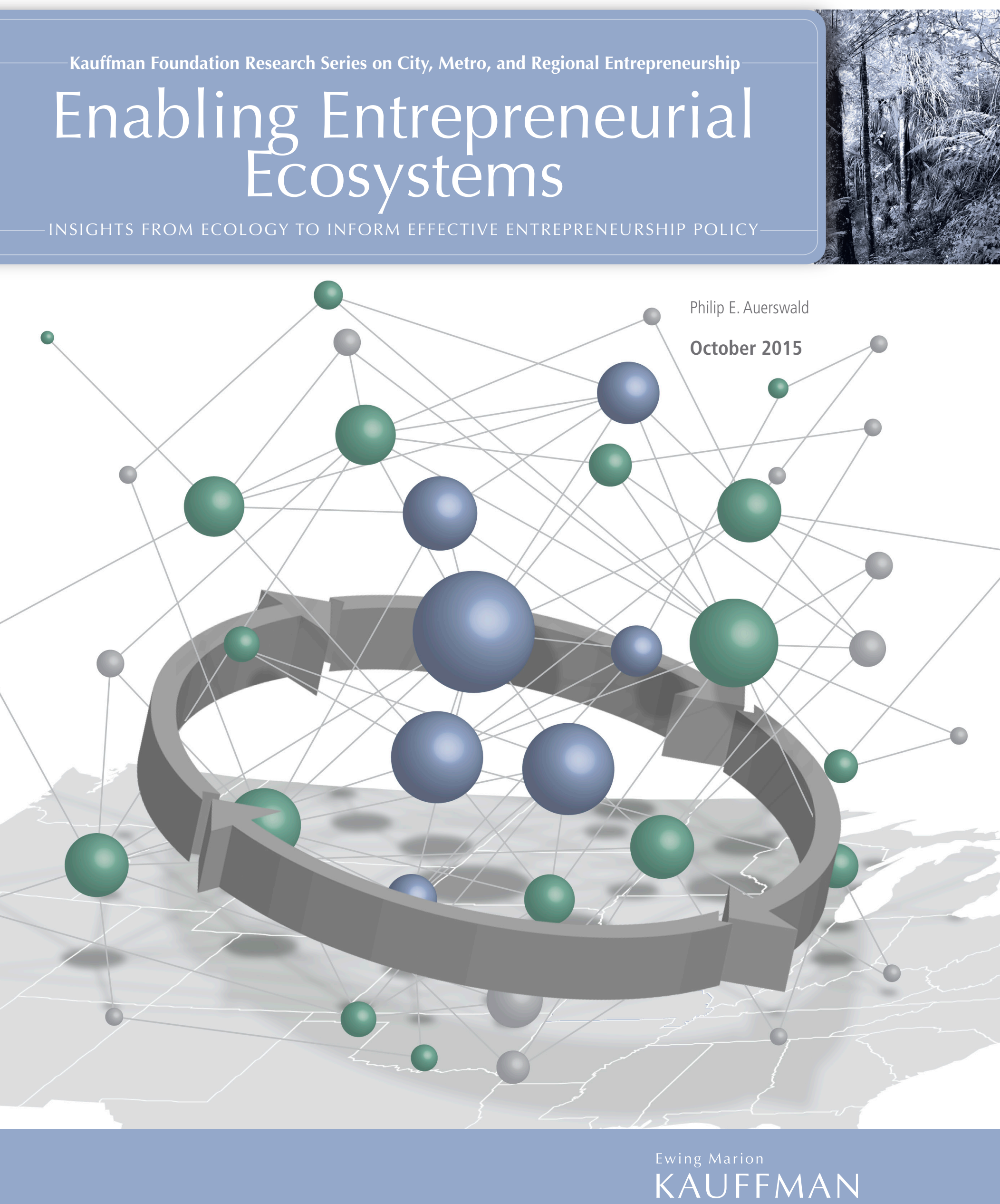


\title{
Enabling Entrepreneurial Ecosystems
}

\author{
INSIGHTS FROM ECOLOGY TO INFORM EFFECTIVE ENTREPRENEURSHIP POLICY
}

\author{
Philip E. Auerswald | October 2015
}

\section{EXECUTIVE SUMMARY}

Inspired by research on the importance of entrepreneurship for sustained economic growth and improved wellbeing, many governments and non-governmental grantmaking organizations have sought over the past decade to implement policies and programs intended to support entrepreneurs. Over this interval, growing appreciation of the limits of strategies focused narrowly on financing or training entrepreneurs has prompted a number of such entities to shift their efforts toward more broadbased strategies aimed at enabling "entrepreneurial ecosystems" at the city or sub-national regional scale.

This paper takes the metaphor of the "ecosystem" seriously, seeking to draw lessons from evolutionary biology and ecology to inform policy for entrepreneurship. In so doing, the paper provides a framework for data gathering and analysis of practical value in assessing the vibrancy of entrepreneurial ecosystems.

Taking the ecosystem seriously as an economic model suggests the following strategies to enable entrepreneurial ecosystems:

- Favor incumbents less. Policies and regulations that favor incumbents-existing, dominant companies—create barriers to entry by new firms and restrict competition. Examples of such regulations include assertive enforcement of non-compete laws, excessively restrictive occupational licensing requirements, and various forms of regulatory complexity that inhibit contracting. Policymakers should avoid enacting such policies and regulations, instead working to reduce the disadvantages faced by entrepreneurial entrants into new and existing markets by favoring incumbents less.

- Listen to entrepreneurs. Rather than develop policies abstractly intended to correct "market failures," policymakers should engage local entrepreneurs in person to develop and implement practically focused policies intended to encourage dynamism, increase diversity, and stimulate "metabolic" activity such as idea exploration, product development, and increased rates of deal flow.

- Map the ecosystem. Create an inventory or graph that indicates who the participants in the ecosystem are and how they are connected. More ambitiously, map roles and differentiate relationships by type, direction, and magnitude of interaction. Once validated by the entrepreneurs and community members, ecosystem maps can become valuable tools in developing strategies for engagement.

- Think big, start small, move fast. This simple rule, which applies to entrepreneurial ventures, also holds true for strategies to enable local entrepreneurial ecosystems. To be effective, such strategies should seek domains for early success and rapidly iterate forward from there to build well-grounded programs at scale.

- Avoid artificially segmenting your community or your strategies.

Entrepreneurs and members of entrepreneurial communities are not potted plants: they are active participants in a range of activities, such as creating new companies, investing in and/or advising startups, 
mentoring entrepreneurs, teaching in formal settings, working at large corporations in research or market development, providing services such as legal or accounting, and serving as customers of entrepreneurial companies. Expect participants in entrepreneurial ecosystems to be playing multiple roles, and make sure to make the most of the unique skillsets of your most versatile community members.

- Prepare to capitalize on crises. Much like a rotting trunk of a fallen tree feeds the growth of new saplings, economic disruption creates entrepreneurial opportunities. Because experiencing disruptions is an inevitable part of economic and social life, those involved in enabling entrepreneurial ecosystems should anticipate them and prepare to make the most of the opportunities they create.

The search for effective strategies to enable local entrepreneurial ecosystems is a fundamentally practical one. Better understanding of actual ecosystems provides a conceptual framework within which policymakers can ask relevant questions, envision better approaches, and evaluate resultant outcomes.

Keywords: algorithms; complexity; entrepreneurship; entrepreneurial ecosystems; local competitiveness; recipes

( 6 t is the systems so formed which, from the point of view of the ecologist, are the basic units of nature on the face of the earth. Our natural human prejudices force us to consider the organisms (in the sense of the biologist) as the most important parts of these systems, but certainly the inorganic "factors" are also parts - there could be no systems without them, and there is constant interchange of the most various kinds within each system, not only between the organisms but between the organic and the inorganic. These ecosystems, as we may call them, are of the most various kinds and sizes. They form one category of the multitudinous physical systems of the universe, which range from the universe as a whole down to the atom."

—Arthur George Tansley?

\section{INTRODUCTION}

Entrepreneurship is present in all societies, but it manifests itself differently depending on the context. ${ }^{2}$ Productive entrepreneurship corresponds to the creation and expansion of new firms; unproductive entrepreneurship corresponds to rent-seeking activities; destructive entrepreneurship corresponds to trafficking in illicit goods. All three forms of entrepreneurship create economic activity; however, institutions advance and societies progress only when the returns to productive entrepreneurship exceed those to unproductive and destructive entrepreneurship. ${ }^{3}$ While there is little evidence that government action can affect the overall supply of entrepreneurs in a given economy, there is strong evidence that it can influence where and how entrepreneurs - or entrepreneurially inclined individuals_-focus their abilities. ${ }^{4}$ Strategies that support development on a national, regional, or local scale thus must consider not only the quality of the general business climate, but also, and importantly, how government actions affect the relative returns to different types of entrepreneurship.

Informed by research on entrepreneurship's importance to sustained economic growth and wellbeing, ${ }^{5}$ non-governmental grantmaking organizations as well as governments around the 
world increasingly have sought strategies to encourage entrepreneurial initiatives and support entrepreneurial ventures. ${ }^{6}$ The growing interest in launching policies and programs that support entrepreneurship has intersected with increasing recognition by very different parties that entrepreneurship is a highly context-dependent activity, with the sub-national region, the city, or even the neighborhood being a more natural scale of analysis than is the nation. Furthermore, experience with programs that support entrepreneurs has called into question the effectiveness of interventions that focus solely on financing entrepreneurs or developing their personal abilities without paying specific attention to the operational context. ${ }^{7}$ As a consequence, institutional innovators inside and outside of government have come to frame entrepreneurship-related interventions as aiming to enable "entrepreneurial ecosystems" specifically at the city or sub-national regional scale as much as to support entrepreneurs directly. ${ }^{8}$

Academic research has failed to keep up with governments' and non-governmental grantmaking organizations' recent interest in entrepreneurship as a central element in local competitiveness. To be sure, as just noted, scholarly research for the past century has addressed entrepreneurship's importance to development and growth. A parallel, comparably robust literature has explored the link between local characteristics and entrepreneurial vibrancy. ${ }^{9}$ However, while rigorous studies abound regarding entrepreneurship, the entrepreneurial process, and national-scale policy initiatives, few comparably rigorous studies have been conducted on the effectiveness of interventions like those on which practitioners are currently focused - that is, those intended to enable local entrepreneurial ecosystems. ${ }^{10}$

There are various reasons for the relative immaturity of the research on entrepreneurial ecosystems at the city or the sub-national regional scale. In this paper, I propose that these reasons include the following: the default theoretical architecture in economics is not well suited to describing entrepreneurial ecosystems, assessing their vibrancy (or lack thereof), or recommending policies that may improve their function. ${ }^{11}$
My objective in this paper is to take the idea of the "entrepreneurship ecosystem" seriously and to consider what sort of guidance researchers and policymakers can gain by making a direct comparison to the substantial literature on ecosystems in the fields of evolutionary biology and ecology. There is, of course, nothing novel in theorizing that economic systems are analogous to biological systems. Nelson and Winter's work is a particularly significant landmark in this literature, but it goes back at least as far as Herbert Spencer's 1857 essay, "Progress: Its Law and Cause." 12 In this paper, I sketch a future path for this line of inquiry, arguing along the way that developments over the last quarter century in both economics and theoretical biology have substantially narrowed the representational gap between economics and the life sciences, to the point where the analogy to evolutionary biology and ecology actually starts to provide some tangible insights into the functioning of economic systems.

The quote that opens this paper is from a 1935 paper by Sir Arthur Tansley, titled, "The Use and Abuse of Vegetational Concepts and Terms," in which Tansley introduced the term "ecosystem." As the quote suggests, evolutionary biologists in the 1930s were as naturally inclined to place "the organism" at the center of their inquiry as economists in that decade were to place "the firm" at the center of production theory. Tansley's insight was that dynamically stable networks of interconnected organisms and inorganic resources constitute their own distinct domain of analysis. Just as I argue in this paper that we cannot consider the entrepreneurial ecosystem simply as a "complex firm," Tansley rebelled against the application of the term "complex organism" to such networks "because the term is already in common use for an individual higher animal or plant, and because the biome is not an organism except in the sense in which inorganic systems are organisms."13

To support that conclusion, I offer some of the ways that, according to the argument that follows, a baseline evolutionary/ecological perspective on entrepreneurial ecosystems departs from the neoclassical/default (Table 1): ${ }^{14}$ 


\section{Table 1:}

Evolutionary/ecological perspective on entrepreneurial ecosystems departs from the neoclassical/default

Default: Entrepreneurship is one factor among many in an economywide aggregate production function.
Evolutionary/Ecological:

Entrepreneurship is not a factor in a fixed, aggregate production function but, rather, the process of creating new firm-level production recipes that can be represented as production functions.
Default: Imperfect appropriability of the returns from an entrepreneurial initiative is a primary impediment to entrepreneurial success because the most valuable firm-level production functions (a.k.a. "recipes") are simple and can easily be copied.

\section{Evolutionary/Ecological:}

Imperfect appropriability of the returns from an entrepreneurial initiative is a secondary impediment to entrepreneurial success because the most valuable firm-level production functions (a.k.a. "recipes") are complex and cannot easily be copied.
Default: Market failures and economic crises undermine entrepreneurs.

\section{Evolutionary/Ecological:}

Market failures and economic crises create opportunities for entrepreneurs.

\section{These theoretical differences also imply different practical strategies to encourage entrepreneurship:}

Default: Entrepreneurship depends on a favorable business climate.
Default: If entrepreneurship generates positive spillovers and thus is an undersupplied input, government policy should subsidize educational institutions to increase their production of entrepreneurs.

\section{Evolutionary/Ecological:}

Entrepreneurship policy potentially can increase economic vibrancy by enabling entrepreneurial ecosystems, but doing so is not as simple as merely subsidizing the production of an undersupplied input.
The bulk of the paper consists of an elaboration of these points.

I begin Section || by defining "entrepreneurship" (following Schumpeter) as the creation of new combinations - a definition that creates a bridge between biological and economic representations of novelty and exchange in ecosystems. In Section III, I describe the relationship between algorithmic complexity (the consequence of the successive creation of new combinations over time) and economic opportunity. In Section IV, I explain how market failures are fundamental to the creation of economic opportunity. In Section V, I address issues of political economy as they relate to the evolution of economic opportunity, and describe how a favorable business climate depends on entrepreneurship. In Section VI, I offer some strategies for enabling entrepreneurial ecosystems that emphasize diversity, dynamism, and deal flow. In Section VII, I offer some cautionary thoughts about using methodologies of formal assessment in implementing strategies to enable entrepreneurship. I conclude my thoughts in Section VIII. 


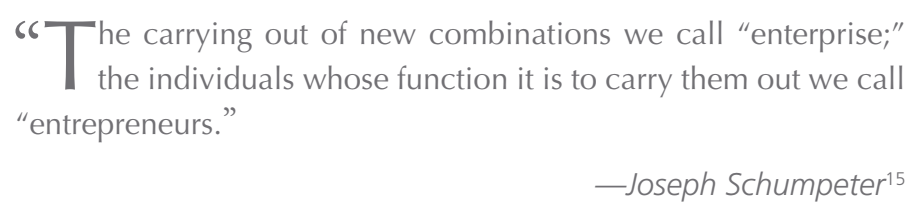

II. ENTREPRENEURSHIP IS THE CREATION OF NEW COMBINATIONS

A word of warning at the outset is in order: throughout this paper I will mix two metaphors, persistently and (mostly) unrepentantly.

The first metaphor is that of the "recipe." This is not really a metaphor, as the culinary recipe is actually a specific example of the general concept to which I am referring. In the first paper to suggest that the recipe might be the basis for a neo-Schumpeterian theory of the firm, Winter (1968) states:

If the technology is that of cake baking, the standard economics of the firm describes that technology solely in terms of the list of ingredients. Here the "ingredients" must be understood to include so many oven-hours, so many labor-hours of the cook, as well as eggs and flour. But "knowing how to bake a cake" is clearly not the same thing as "knowing how to bring together all of the ingredients for a cake." Knowing how to bake a cake is knowing how to execute the sequence of operations that are specified, more or less closely, in a cake recipe. The list of ingredients is understood to be contained in the recipe, but the recipe is not fully revealed by the list of ingredients. ${ }^{16}$

Production recipes are implicit in the neoclassical theory of production, but they are not explicitly represented anywhere. ${ }^{17}$ But the basic idea is very simple: a recipe is just the algorithm employed to transform inputs into outputs (where the outputs may be a service or another recipe), more or less exactly as in the culinary instance.
The second metaphor is that of the "ecosystem," as just described. From a modeling standpoint, the connection is a natural one: the model of production recipes introduced in Auerswald et al. (2000) is itself based on a specific formalization of "fitness landscapes" within evolutionary biology introduced by Kauffman and Levin (1987), which, in turn, derives from Wright (1932). When I appeal to the conceptual structure of the ecosystem to describe the environment in which entrepreneurs operate, algorithms of production will correspond to genotypes (also analogous to recipes); specific firms employing those algorithms will correspond to phenotypes; entrepreneurship will correspond to genetic recombination; and the creation of new industries will correspond to speciation. ${ }^{18}$

I will thus use "new combinations" and "new production recipes" interchangeably when referring to entrepreneurship:

\section{Creating new combinations $\uparrow$ Creating new production recipes $\hat{\imath}$ Entrepreneurship}

Just like culinary recipes, production recipes are comprised of discrete tasks that yield a well-specified output when performed in combination. The individual tasks themselves can be the subject of experimentation. Each task may be refined, and different arrangements of tasks (which is to say, different recipes) will result in different outputs. Importantly, some tasks may be performed using tacit knowledge and therefore will not be encoded anywhere.

The next section defines complexity in production, upon which is based my definition of progress in regional development-and therefore the ultimate source of local competitiveness. 
(
is to see bridges where others see holes.

-Ronald Burt ${ }^{29}$

\section{COMPLEXITY DRIVES OPPORTUNITY}

In one of the most highly cited papers in the management literature, Teece et al. (1997) wrote: "The competitive advantage of firms is seen as resting on distinctive processes (ways of coordinating and combining), shaped by the firm's (specific) asset positions (such as the firm's portfolio of difficult-totrade knowledge assets and complementary assets), and the evolution path(s) it has adopted or inherited." 20 The competitive advantage of regions is similarly in capabilities that are not easily copied or replaced by tradable goods. ${ }^{21}$

This statement and the above discussion of "production recipes" both suggest that the ideas that actually propel growth and development are overwhelmingly uncodified, context dependent, and transferable only at significant cost-which is to say, tacit knowledge dominates, information asymmetries are the norm, and transaction costs are significant. ${ }^{22}$ To the extent that a new method is easily imitable, the profits earned by an innovator will be short lived. ${ }^{23}$ Imitation of complex production recipes is almost always imperfect-sometimes disastrously so—because modifications in the practices of one unit within the firm will affect the effectiveness of multiple other units. ${ }^{24}$ Because a simple production recipe can easily be imitated, it is not likely to yield persistent "above normal" profits to an early adopter. The most enticing opportunities for disruptive entrepreneurship are typically those that require the greatest coordination and have the greatest inherent complexity, as these ventures are the most difficult to imitate when successfully launched..$^{25}$ The primary pathway by which complexity affects market structure and local competitiveness is via the obstacles to imitation that complexity may endogenously create.

Given the continued influence of the specific New Growth formulation famously advanced by Romer $(1986,1990)$, in which ideas are "non-rival" and "nonexcludable," and economically relevant innovations are characteristically subject to "knowledge spillovers," 26 it is worth emphasizing that the information-theoretical/ ecological perspective advanced in this paper implies that entrepreneurship characteristically involves the search for ideas that are, in fact, rivalrous and excludable (at least temporarily), out of which ventures with proprietary value can be created. Furthermore, while "knowledge spillovers" of the type emphasized by Romer (and followers) clearly exist, they are of marginal relevance in the practical work of creating the new business entities that drive economic growth and development. ${ }^{27}$ The impediments to entrepreneurship that matter most are the everyday battles involved in communicating ideas, building trust, and making deals. ${ }^{28}$ Efforts to enable entrepreneurial ecosystems must be directed toward easing these struggles.

The next section is devoted to correcting another conceptual error often made in conceiving strategies to enable entrepreneurial ecosystems: that the goal of interventions is to reduce or eliminate (static) market failures. We shall see that the opposite is true; that is, (static) market failures provide a vital source of energy to propel entrepreneurial initiatives. It is because market failures are pervasive and self-renewing that entrepreneurship-in one form or another-is a globally ubiquitous phenomenon. 
‘( There is no such thing as a low-tech industry. There are only low-tech companies."

$$
\text { -Michael Porter }{ }^{19}
$$

\section{MARKET}

\section{FAILURES CREATE OPPORTUNITIES FOR ENTREPRENEURS ${ }^{30}$}

Whereas conventional wisdom among economists and policymakers is that eliminating market failures will encourage entrepreneurial activity, the reality is that the greater the intensity of a market failure, the stronger the potential value of an entrepreneurial new combination.

At one level, this claim can be justified in a very straightforward manner: in an environment of perfect competition where the actions of existing firms fulfill the first welfare theorem (Pareto efficiency achieved via market transactions) and the actions of government fulfill the second welfare theorem (equity achieved via ex post redistribution of wealth), there would be no market space for, much less need for, entrepreneurship. Even allowing for short-term rigidities in entry and exit and exogenously driven fluctuations in demand, the only motivation to create a new venture would be to replicate an existing economic combination. ${ }^{31}$

In the Coasean framework, transaction costs are the glue that holds a firm together. When the magnitude of transaction costs increases somewhere in the economy, it follows that new firms may be created and existing firms may either combine or expand (by incorporating transactions previously mediated through the market). ${ }^{32}$

Burt (2004) takes this further, describing how transaction costs combined with information asymmetries are not only the basis for intellectual arbitrage but also for the creation of new conceptual combinations. In prior work, Burt established the critical role played by the few people within an organization who have the capacity to bridge the "structural holes" that exist as a natural consequence of functional specialization and the separation of organizations into distinct clusters. Burt (2004) extends this to describe how those same individuals are disproportionately responsible for creating new ideas: "Whether in communities or in a geographical region, divisions in a corporation, groups within a profession, or members of a team, people specialize within clusters and integrate via bridges across clusters." 33

The structural holes both within and between organizations that Burt has documented in a substantial body of work exist due to market failures of various types. They create opportunities for those who "see bridges where others see holes" - a concise description of the entrepreneurial mindset. Ironically, then, the renewal of structural holes-and the persistence of the market failures on which they are based-is a prerequisite for entrepreneurship. ${ }^{34}$

Until recently, the relationship between complexity, capabilities, and development was a matter of conjecture. However, thanks to a groundbreaking empirical study published in 2009 and further work since by Ricardo Hausmann, César Hidalgo, and their coauthors, this conjecture is at last being subject to empirical testing. Hausmann and Hidalgo summarize their results as follows:

We have presented a technique that uses available economic data to develop measures 


\section{The source of regional technological advantage lies not in vague and unmeasurable knowledge spillovers but in the highly tangible flexibility of economic actors to organize and reorganize flexibly as the need arises. ${ }^{39}$}

of the complexity of products and of countries, and showed that (i) these measures capture information about the complexity of the set of capabilities available in a country; (ii) are strongly correlated with income per capita; (iii) are predictive of future growth; and (iv) are predictive of the complexity of a country's future exports, making a strong empirical case that the level of development is indeed associated to the complexity of a country's economy. ${ }^{35}$

The approach taken in Hidalgo and Hausmann (2009), Hausmann and Hildalgo (2011), and Hausmann et al. (2011) is fundamentally combinatorial, inspired (like this paper) by Kauffman $(1988,1993)$ and synchronous with Weitzman (1998). The matrix of products and underlying capabilities that is the core of the analysis in Hidalgo and Hausmann (2009) corresponds quite closely to an economic food web, in which less-complex production recipes create products that are then "consumed" by more-complex production recipes — very much in keeping with the classic notion of succession in biological systems, as described by Tansley above. ${ }^{36}$

While Hausmann and Hildalgo have conducted their work on maps of economic complexity at the national level, only data limitations impede the application of their model to a sub-national region. At that scale, Jacobs $(1961,1969,1984)$ was the first to relate the creation of new combinations to growth and development, thereby advancing the hypothesis that diversity, not specialization, is the key to vitality in cities. ${ }^{37}$ A pioneering empirical study of growth in a cross-section of U.S. cities by Glaeser et al. (1992) found that, "at the city-industry level, specialization hurts, competition helps, and city diversity helps employment growth." Subsequent studies by Henderson et al. (1995) and Feldman and Audretsch (1999) concluded that economic diversity is important in explaining new firm creation and innovative output, respectively.

Saxenian (1994) argues similarly that regions in this view are best understood "as networks of relationships rather than as collections of atomistic firms." 38 The source of regional technological advantage lies not in vague and unmeasurable knowledge spillovers but in the highly tangible flexibility of economic actors to organize and reorganize flexibly as the need arises. ${ }^{39}$ In a detailed study of Silicon Valley social networks, Castilla et al. (2000) note that "dense networks not only within but between sectors of engineers, educators, venture capitalists, lawyers, and accountants are important channels for the diffusion of technical and market information." The exchange of ideas within such networks is largely purposive, building "weak ties" that facilitate transactions. ${ }^{40}$

In regional economics, these results are well known. What the work of Hausmann and Hildalgo has done is to indicate for the first time the existence of a bridge between formal microeconomic models of production grounded in evolutionary biology and the sort of structure-preserving empirical inquiry that takes the ecological metaphor seriously.

In the next section, I go in a different direction to discuss how considerations of political economy bear upon the design and implementation of strategies to enable entrepreneurial ecosystems. Then, in sections $\mathrm{VI}$ and $\mathrm{VII}$, I refer back to complexity to offer some suggestions for practical strategies to enable entrepreneurial ecosystems. 
،6 modern economy is a wondrously complex system that continually A converges toward general equilibrium. But it always fails to reach equilibrium because it incessantly faces new opportunities and shocks. There is not even enough information to calculate the present situation of an economy with any detail or accuracy, much less its future position . . Because uncertainties are so pervasive and unfathomable, the most dynamic and prosperous societies are those that try many, many different things. They are societies with countless thousands of entrepreneurs."

-Mancur Olson ${ }^{41}$

V. A FAVORABLE BUSINESS CLIMATE DEPENDS ON ENTREPRENEURSHIP

Support for entrepreneurship and innovation is often confused with generic strengthening of the overall "business climate." What is the difference? The business climate pertains to all firms-both incumbents and new entrants. Some elements of the business climate (e.g., the time required to register a new business or the difficulty of obtaining business licenses) are particularly relevant to entrepreneurship. However, others (e.g., the stability of the financial sector) may actually reflect the concentration of market power and barriers to entrepreneurial entry. ${ }^{42}$

Entrepreneurship of the type I focus on in this paper (i.e., Schumpeterian entrepreneurship) is an inherently disequilibrium phenomenon that takes place in a world characterized by uncertainty, asymmetric information, indivisibilities, and non-zero transaction costs. As Mancur Olson put it (see quote above), "Because uncertainties are so pervasive and unfathomable, the most dynamic and prosperous societies are those that try many, many different things. They are societies with countless thousands of entrepreneurs." 43

This is the very reason why entrepreneurship policy has come to the fore in countries around the world. Development is an ongoing process of social change, and one subject to regular disruption, that involves institutions, culture, and technology. While societies can advance for a short while by making incremental adjustments to the status quo, long-term development requires entrepreneurship and innovation. As Hirschman noted, "Development depends not so much on finding optimal combinations for given resources and factors of production as on calling forth and enlisting for development purposes resources and abilities that are hidden, scattered, or poorly utilized. "44

Entrepreneurs and innovators exist in all societies, but not all societies are equally welcoming of the disruptive changes they provoke. Individual entrepreneurs and innovators thus face three options: seek economic rents within the status quo; challenge the status quo through disruptive innovation; or leave the society altogether to seek an environment more welcoming of economic creativity. These three options (taken in reverse order) are analogous to the fundamental political options articulated by Hirschman long ago: exit, voice, and loyalty. ${ }^{45}$

When too large a portion of potential innovators and entrepreneurs choose either to seek rents within the context of the status quo or to leave the society altogether, development slows or comes to a halt. If the above statements are in fact true, then creating a place for the future in any country means creating a space for entrepreneurship and innovation-and, in particular, encouraging the subset of potential entrepreneurs and innovators who choose neither to conform nor to depart but to stay and build something new. 
Conventional wisdom holds that a country can become a 21st-century entrepreneurial economy only after its political institutions have fully matured. However, the actual development experience of advanced industrialized economies arguably tells a different story: a country's political institutions mature only as its economy produces broad-based opportunities on a sustainable basis. ${ }^{46}$ If so, then internal security and political stability are not prerequisites for, but the consequence of, broadbased social development that is driven by competition and entrepreneurship and supported by increasing levels of social trust. Actions taken in the name of near-term stability that undermine competition and economic dynamism not only make a country less prosperous, they also make it (dynamically) less secure and less stable.

If there is more to enabling entrepreneurial ecosystems than "strengthening the business climate," then what constitutes a viable strategy or set of strategies? I consider this question next.

c6 $\mathrm{n}$ entrepreneurial ecosystem implies cooperative and productive Irelationships among different organizations. In many countries, these relationships are between startups, established companies, universities, and research institutions. In a vibrant ecosystem, people and ideas flow between these organizations, starting new ventures, joining existing ones, and linking innovations together."

-Global Entrepreneurship Congress ${ }^{47}$

\section{PROMOTE}

\section{DIVERSITY, ECOURAGE DYNAMISM, AND DRIVE DEAL FLOW}

As early as 1963, anthropologist Clifford Geertz noted of Javanese traders, "What the entrepreneurial group of ... small businessmen most lacks is not capital . . . or drive . . . or a sufficient market. What they lack is the power to mobilize their capital and channel their drive in such a way as to exploit the existing market possibilities. They lack the capacity to form efficient economic institutions; they are entrepreneurs without enterprises. "48 A half-century later, a huge disparity still exists between low- and high-income countries in terms of what small and growing businesses contribute to economic growth and employment.

The relative dearth of small and growing businesses in low-income countries is sometimes referred to as the missing middle. The motivation for this term is illustrated by Figure 1 from Ayyagari et al., which displays the historical contributions made to economic output and employment by small and medium enterprises (SMEs) in both low- and high-income countries. The contrast is striking and significant. In high-income countries, SMEs are responsible for more than half of both gross domestic product (GDP) and employment; in low-income countries, SMEs count for less than one-fifth of GDP and employment, and the dominant contributors to 


\section{Figure 1. Small and medium enterprise (SME) contribution to GDP and employment in low-income and high-income countries.}

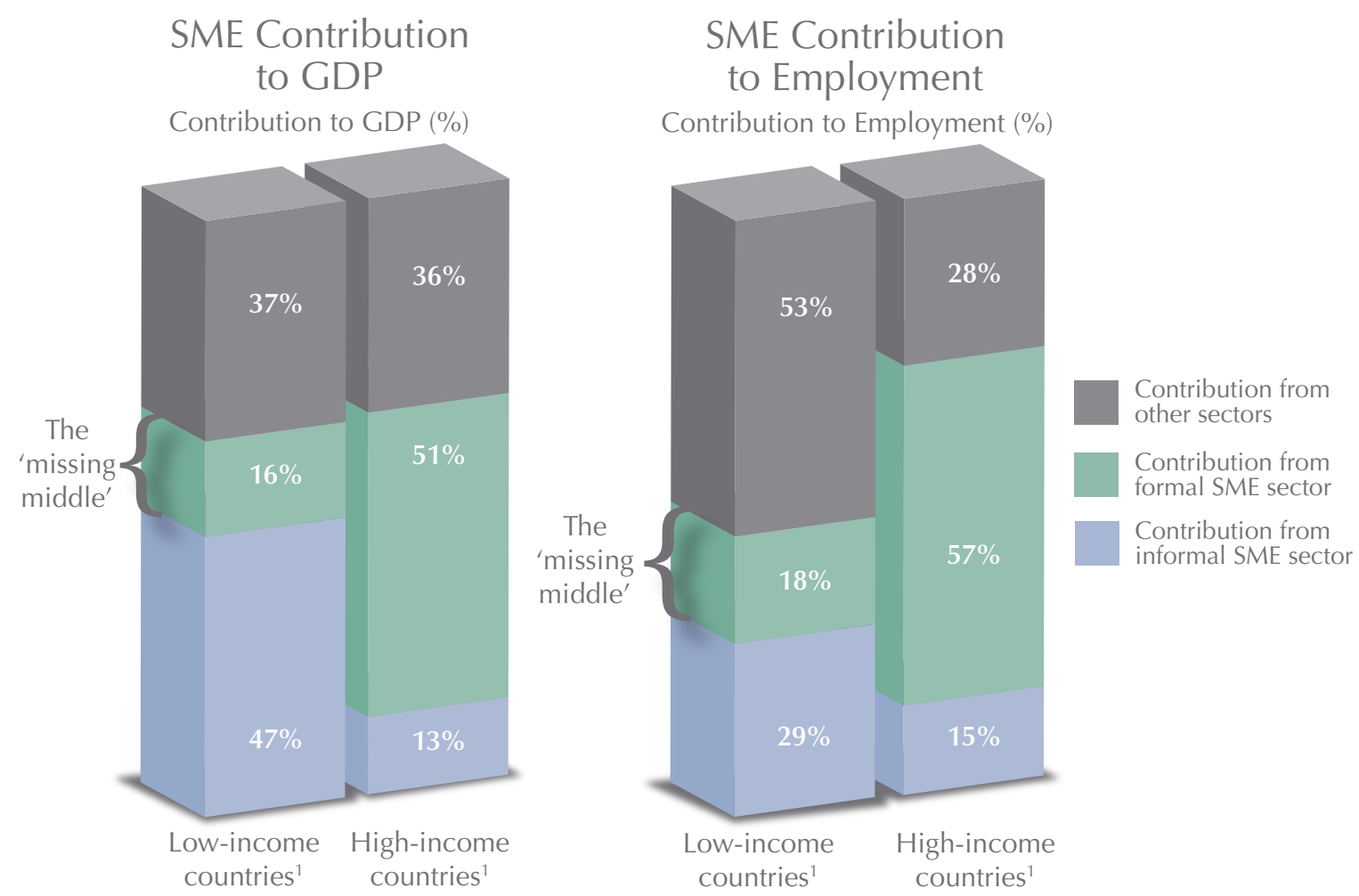

1. Contribution percentages are medium values for income group.

Source: Aspen Network of Development Entrepreneurs (2009), based on data from Ayyagari et al. (2003).

Reprinted under Creative Commons License.

economic activity are the unregistered microenterprises that constitute the "informal sector." 49

There is more to these figures than simple accounting. These data represent the fundamental economic imbalances present in places that lack dynamic entrepreneurial ecosystems. Institutional resources that are taken for granted in the most successful entrepreneurial regions-access to managerial talent, mentoring, and growth capital-are, in many places, absent or insufficient. As a result, in the places that would most benefit from entrepreneur-led development, talent is trapped in two places: in very small, low-productivity microenterprises that have little potential for expansion, capital accumulation, or job creation; and in very large ventures that benefit from economies of scale but often lag behind their SME counterparts in terms of innovation and growth.

While all new and rapidly growing firms initially fall into the category of SMEs, it is important to note that - data in Figure 1 notwithstanding-implementing strategies to accelerate entrepreneurship is not the same as building institutions to support SMEs. SMEs are small, but they are not necessarily new or growing. Schumpeterian ventures are new and innovative, 
but when successful they do not remain small or midsize for long. Indeed, programs to support SMEs, if improperly conceived and implemented, may actually undermine entrepreneurship if they diminish incentives for entrepreneurial innovation and growth-directed strategies_-for example, by creating a program of subsidies not available to firms that grow beyond a certain size.

A failing entrepreneurial ecosystem is one in which there is no viable bridge linking small and large firms. Small family businesses are essentially precluded from growing into large firms due to limitations of managerial oversight; large corporations rarely invest in or develop small enterprises. Even buyer-supplier relationships with subcontractors-which are key to the functioning of large firms in advanced industrialized countries-are either poorly developed or absent in most industries. The economic environment lacks, in addition to trust, an ecosystem that connects the various levels of the private sector: large corporations, innovative high-growth firms, and microenterprises. As in a rainforest (see Figure 2), the challenge is how to bring all of those levels into an ecosystem where they're working and reinforcing one another.

My argument so far suggests that there is every reason to believe that the underlying problem solved by an entrepreneur will be complex and, consequently, that any solution found to the problem will not be easily copied. Furthermore, as Olson describes, there is ample reason to believe that well-intentioned

Figure 2. The forest ecosystem

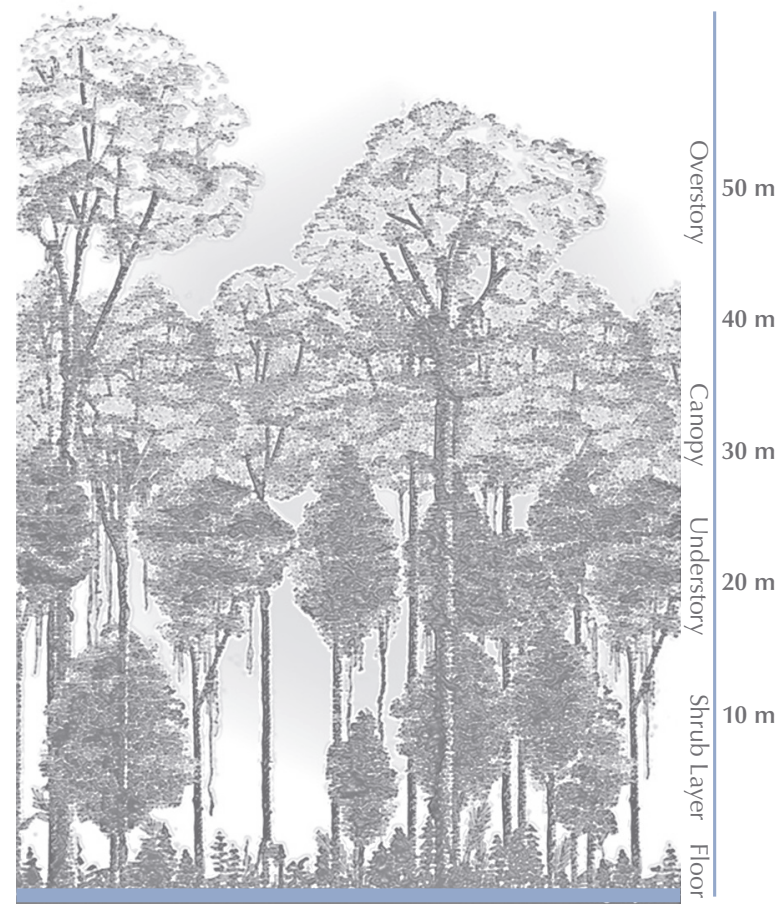

Source: Mongabay.com. Reprinted under Creative Commons license. 


\section{Entrepreneurs repeatedly report that conventional tools of business-friendly policy, such as tax incentives, grants, and local regulations, have little relevance to their success or to the vitality of local entrepreneurial ecosystems.}

efforts to create a "business-friendly" environment are likely to result in interventions that enhance, or at least reinforce, the advantages of marketleading incumbents. ${ }^{50}$ If this is true, then the implied strategy is very different: rather than seeking to build product-based clusters through targeted subsidies for incumbent firms, political actors and policymakers should, whenever feasible, seek opportunities to reduce subsidies for incumbents and broaden pathways for entrepreneurs to enter domestic markets.

Entrepreneurs repeatedly report that conventional tools of business-friendly policy, such as tax incentives, grants, and local regulations, have little relevance to their success or to the vitality of local entrepreneurial ecosystems. Entrepreneurs instead emphasize the importance of access to networks, quality of life, and other intangibles. A recent report by Endeavor (a global organization dedicated to supporting entrepreneurs), based on interviews of 150 founders of high-growth firms in the United States, found the following:

- $\quad$ Entrepreneurs at fast-growing firms usually decide where to live based on personal connections and quality of life factors many years before they start their firms.

- $\quad$ These founders value a pool of talented employees more than any other businessrelated resource that cities can offer.

- Access to customers and suppliers is the second most valuable business-related resource that cities can provide, according to these entrepreneurs.

- $\quad$ The founders in our study rarely cite low tax rates or business-friendly regulations as reasons for starting a business in a specific city. ${ }^{51}$
A World Economic Forum survey of more than 1,000 entrepreneurs in forty-three countries found similarly that the elements of the ecosystem of greatest concern to entrepreneurs are funding and finance, human resources, and market opportunity, with government and regulatory issues a comparably significant concern only among entrepreneurs in the Middle East and Africa. ${ }^{52}$

Given these realities and the foregoing analysis, I offer a few principles for enabling entrepreneurial ecosystems:

Favor incumbents less. Where governments and multinational institutions such as the World Bank have become increasingly interested in identifying and implementing programs to support entrepreneurs, they also have continued to engage in conventional development practices that arguably have the unintended consequence of obstructing the emergence of the very entrepreneurial culture that the former programs seek to develop. Given these realities, wherever particular actors in national governments and international NGOs who are interested in supporting entrepreneurs have the latitude to do so, they should focus primarily on adjusting the full portfolio of interventions so it favors incumbents less. There may be little point in creating a single program to enable entrepreneurial ecosystems if ten other programs exist in parallel that undermine entrepreneurs' ability to succeed because they intensify the power of entrenched economic (and, often, political) incumbents - in both the "beneficiary" country and the "donor" countries. Subsidies to incumbent firms (both direct and indirect) and other policies aimed at short-term goals such as job creation may end up being counterproductive when their longer term, dynamic effects on competition are taken into consideration. 


\section{Regulatory advantages governments confer on incumbents are at least as damaging to the emergence of entrepreneurial ecosystems as fiscal advantages are.}

Regulatory advantages governments confer on incumbents are at least as damaging to the emergence of entrepreneurial ecosystems as fiscal advantages are. For example, Starr et al. (2014) discussed the increasing use of non-compete agreements in the U.S. labor force as a deterrent to entrepreneurial entry and competition; Kleiner and Krueger (2013) and Kleiner et al. (2014) undertake a similar analysis focused on occupational licensing. Generally, from the standpoint of standard theory, there are at least four ways in which regulation may create obstacles to entrepreneurs seeking to enter an industry with service-improving innovations:

1. By increasing the overall cost of doing business within an industry ${ }^{53}$

2. By explicitly treating incumbents more favorably than new entrants ${ }^{54}$

3. By implicitly imposing a regulatory risk on new entrants that is greater than that faced by incumbents

4. By creating regulatory complexity that favors incumbents who have already worked their way down "compliance learning curves" 55

Of these dimensions of regulations' impact on competition, all but the fourth have been studied extensively as "unintended consequences" that should be considered by a presumably dispassionate regulator. ${ }^{56}$

There are many structural reasons why we might expect regulatory agencies to represent the interests of the most powerful incumbents rather than those of new entrants. As venture capitalist and complexity theorist John Chisholm observes, "Industry regulations co-evolve over decades with the major players in those industries. Just having lived through and intimately knowing the regulatory history gives entrenched players an advantage over new entrants, and regulatory complexity works to the benefit of these entrenched players. " 57 The longer an industry exists as a well-defined market entity (implying multiple dimensions of underlying market stability), the more likely that incumbents will employ regulation as an anticompetitive tactic.

The conscious use of regulation by incumbent firms as an entry-constraining tactic is analogous to what biologists refer to as "defensive complexity." Using the more general term "control systems" as a biological equivalent for economic "regulation," Chastain, Antia, and Bergstrom (2012) describe how, when incumbents employ defensive complexity as a strategy, stasis rather than dynamism can result in otherwise highly competitive environments: "Where sufficient defensive complexity is in place, antagonistic co-evolution can lead to long periods of structural stasis instead of rapid change." 58

Listen to entrepreneurs. As Rodrik points out, "The conventional approach to industrial policy consists of enumerating technological and other externalities and then targeting policy interventions on these market failures. The discussion then revolves around the administrative and fiscal feasibility of these policy interventions, their informational requirements, their political-economic consequences, and so on." 59 This default process generally leaves the ostensible "beneficiaries" of policy-entrepreneurs and members of the communities in which they reside-on the sidelines until a policy is implemented. Such an approach simply cannot work if the objective is to enable entrepreneurial ecosystems. For one thing, the objective is not to address market failures but to encourage dynamism, promote diversity, and, above all, increase metabolic activity (ideas explored, products 
prototyped and sold, services offered, deals closed) in a particular locality. These activities cannot take place at a distance. They require not only positive engagement but also responsive listening. As Motoyama et al. found in their study of a particular effort to enable the entrepreneurial ecosystem in Kansas City, "If the public sector or entrepreneurship support organizations attempt to engage entrepreneurs, they should target local sources and in-person events." 60

Map the Ecosystem. Creating open and trusted lines of communication between members of entrepreneurial communities and those who would support, and grow, their efforts creates a context in which it is possible to map the entrepreneurial ecosystem. At its simplest, an ecosystem map is a simple relational inventory (or graph) that indicates who the participants in the ecosystem are (nodes) and how they are connected (edges). More ambitiously, a map may describe roles and differentiate relationships by type, direction, and magnitude of interaction. The particulars of the map matter less than what it is used for-to identify central players, key relational structures, and linked domains of capabilities. Once validated by the entrepreneurs and community members, ecosystem maps may become valuable tools in developing strategies for engagement.

Think big, start small, move fast. ${ }^{61}$ This simple rule, which applies for entrepreneurial ventures, also holds true for strategies intended to enable local entrepreneurial ecosystems. Adaptive learning is not just an assessment methodology; it is the practice of implementation itself. Seek domains for early success and rapidly iterate forward from there to build wellgrounded programs at scale.
Avoid artificially segmenting your community and your strategies. The ecosystem metaphor helps remind those planning interventions that entrepreneurs and members of entrepreneurial communities are not potted plants: they do not conform to fixed categories, and they do not remain still. Active participants in entrepreneurial ecosystems typically will sequentially or simultaneously engage in more than one of the following activities:

- $\quad$ Leading or being part of an entrepreneurial team in the creation of a new venture

- Acting as an equity investor in, and/or formal advisor to, one or more other ventures

- Mentoring other entrepreneurs

- $\quad$ Teaching in a formal setting

- Working at a large corporation either in research and development or market-facing activities

- Providing a service (legal, marketing, accounting, etc.) to entrepreneurs and new ventures

- $\quad$ Acting as a buyer for goods and services provided by entrepreneurs and new ventures

Expect participants in entrepreneurial ecosystems to be playing multiple roles and make sure to make the most of the unique skillsets of your most versatile community members..

Prepare to capitalize on crises. In a rainforest, the rotting trunk of a fallen tree feeds the growth of new trees by releasing nutrients formerly locked within its cell walls. These "spinoff" saplings are doubly well-positioned by being naturally situated above a nutrient source on the forest floor and below a newly

\section{At its simplest, an ecosystem map is a simple relational inventory (or graph) that indicates who the participants in the ecosystem are (nodes) and how they are connected (edges).}


created gap in the canopy above. Sunlight to a sapling is comparable to customers to a small and growing firm. Figure 3 provides a graphical representation of the dynamics of exploitation, conservation, release, and reorganization in a forest ecosystem, including reference to the ecological concept of succession that I introduced at the start of this paper.

A directly analogous phenomenon occurs in economic ecosystems. Simply put, disruption creates entrepreneurial opportunities. This holds at both the regional level and the firm level. In the mid-1950s, the economy of the Santa Clara Valley in California was disrupted when (following the end of the Korean War) then-secretary of defense Charles Erwin Wilson cut the U.S. military budget by $\$ 11$ billion, eliminating 40,000 civilian jobs along the way. ${ }^{62}$ These cuts coincided with the beginning of an era in that region in which a significant number of radio and electrical engineers joined or created the companies that turned the northern end of Santa Clara Valley into Silicon Valley. When the Defense Department made cuts of a comparable magnitude in the mid-1980s, entrepreneurial ecosystems in Northern Virginia and in San Diego received a similar boost. ${ }^{63}$

\section{Figure 3. Succession and reorganization of ecosystem as represented by Bengtsson et al.}

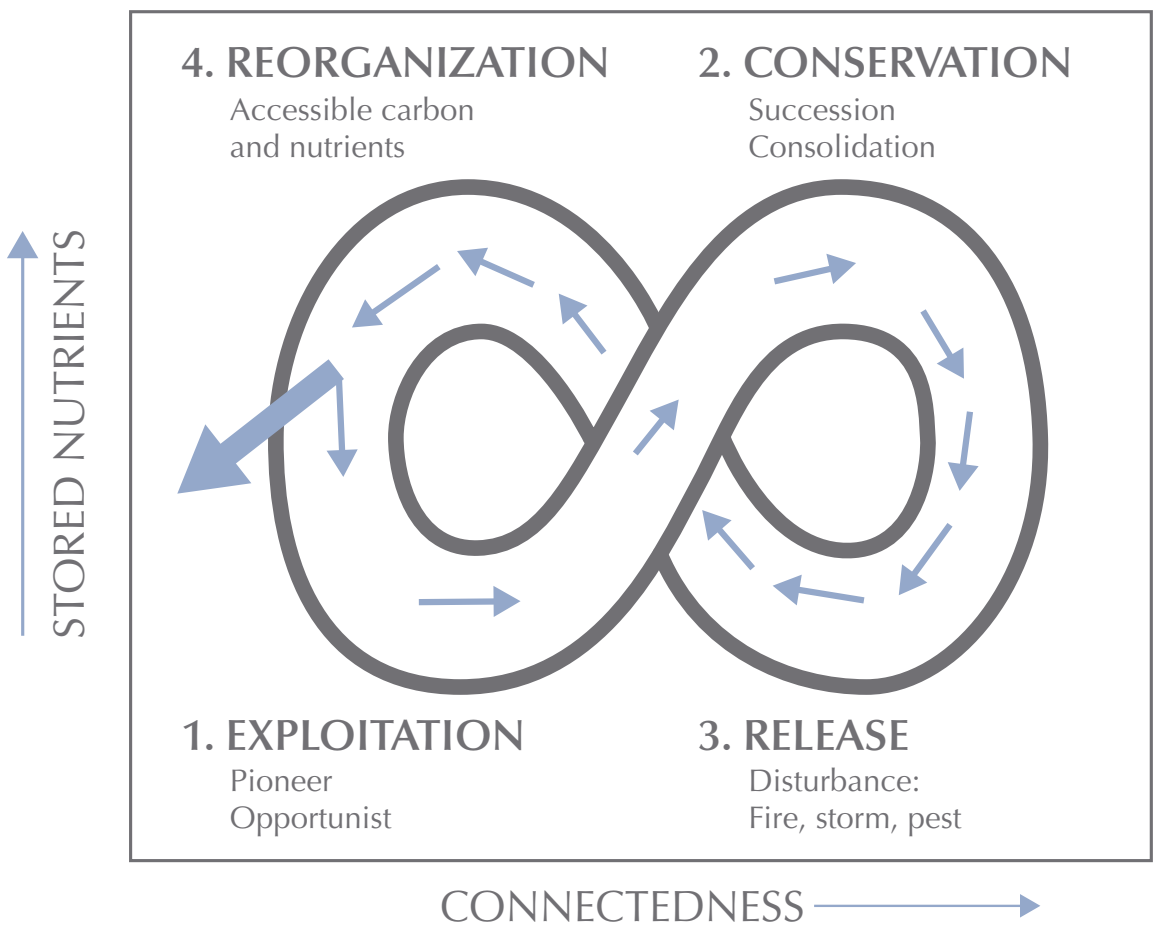

Arrows close to each other indicate rapid changes; arrows far from each other indicate slow changes. Following Holling et al. (1995), Bengtsson et al. (2000) note that "diversity in forested landscapes is needed for the transitions between all the four stages, which is why managed forests must be managed so a sufficient number of species is available for the cycle to continue.

Source: Image from Bengtsson et al. (2000). 
Providing further evidence of a positive correlation between economic disruption and entrepreneurial opportunity at a national scale in the United States, Stangler finds that more than half of the Fortune 500 companies were started during a recession. ${ }^{64}$

The international evidence does not contradict the conjecture that disruption creates entrepreneurial opportunity. In the power vacuum that followed the death of Mao Zedong, farmers in the People's Republic of China who had formerly been tied to rural collectives - with truly catastrophic results-were left by the state to enjoy new autonomy. They went back to what came naturally - family-based farming on small plots of land. In 1979, under the leadership of Deng Xiaoping, the Chinese government implemented reforms to codify the return of family-based farming. The immediate consequence was increased agricultural productivity, but the implications reached well beyond rural areas and grain silos. The practical impact of these reforms was, as Huang has documented, to initiate a long-term process in which roughly a fifth of the world's population would have new opportunities to seek, and create, opportunities for themselves. ${ }^{65}$ Rapid entrepreneur-led renewal also has recently occurred in once-devastated parts of Rwanda (centered on Kigali) and Colombia (centered on Medellín).

The take-away here is not, of course, that leaders in society should engineer large-scale disruptions in order to realize future benefits, nor am I suggesting that the more dramatic disruptions to which I just alluded are desirable. Rather, I am proposing that because experiencing disruptions is an inevitable part of social life-though customarily such disruptions are less severe than those experienced in recent decades in China, Rwanda, and Colombia-those involved in the project of enabling entrepreneurial ecosystems should anticipate them and prepare to make the most of the opportunities for the beneficial change they create.

Before concluding, I offer a final comment on the important topic of program assessment.

، The introduction of rapid response systems in hospitals is a complex, multicomponent intervention-essentially a process of social change. The effectiveness of these systems is sensitive to an array of influences: leadership, changing environments, details of implementation, organizational history, and much more. In such complex terrain, the RCT [randomized controlled trial] is an impoverished way to learn. Critics who use it as a truth standard in this context are incorrect."

—Donald Berwick ${ }^{66}$

\section{FORGET ABOUT "GOLD STANDARDS"}

I have emphasized that entrepreneurial ecosystems are highly complex, interdependent environments whose function can be reduced only with a high degree of imperfection to a single index or even to an array of indices. To the extent that small changes in experimental conditions lead to large changes in outcomes-that is, to the extent that the policy itself involves the implementation of a complex recipethen the likelihood that a study conducted in setting $X$ will be relevant to setting $Y$ (or even to setting $X$ in the future) is correspondingly diminished. Hausmann succinctly describes the manner in which complexity undermines the notion of gold-standard research in development practice:

A typical program, whether a conditional cash transfer, a micro-finance program or a health intervention can easily have fifteen relevant 
dimensions. Assume that each dimension can only take two values. Then the possible combinations are 215 or 32,768 possible combinations. But randomized trials can only distinguish between a control group and one to three treatment groups. So, many of the design or contextual features are kept constant while just one or three are being varied. This means that the search over the design space is quite limited, while the external validity of these experiments is reduced by the fact that many of the design or contextual elements are bound to change from place to place. So, for the majority of the design elements, choices must be made in the absence of the support from randomized trials, which will necessarily play a secondary role in the actual practice of policymaking. ${ }^{67}$

The internal validity of RCTs says nothing about their external validity. As Berwick states regarding the use of RCTs to inform innovation in public health (see quote above), "In such complex terrain, the RCT is an impoverished way to learn." 68 The same argument holds with regard to the use of RCTs as a practical tool to assess and develop strategies to enable entrepreneurial ecosystems. While RCTs may be methodologically elegant, they are not necessarily of any greater practical value than are structured interviews, surveys, relational maps, (theory-informed) data mining, or any of an array of methodologies that can increase understanding of a particular ecosystem at a particular time.

When it comes to methodologies to assess strategies intended to enable entrepreneurial ecosystems, there is no gold standard. Quality assessments will be those that are carried out according to a clearly defined baseline, connected to the reality of the particular ecosystem (or ecosystems) in question, and updated on a regular basis. In most cases, such assessments -informed equally by common sense and the desire for methodological simplicity—will yield information that is more practically useful and at least as generalizable as the ostensible gold standard.

c6 score of Tatas might do more for India than any government, British Aor indigenous, can accomplish.."

-Alfred Marshall ${ }^{69}$

\section{CONCLUSION}

The search for strategies to enable local entrepreneurial ecosystems is a fundamentally practical one, for which current academic research does not provide ready answers or even compelling conceptual frameworks within which to ask relevant questions. Better understanding of actual ecosystems provides a conceptual framework within which policymakers can ask relevant questions, envision better approaches, and meaningfully evaluate resultant outcomes. 


\section{REFERENCES}

Acs, Zoltan J., David B. Audretsch, Pontus Braunerhjelm, and Bo Carlsson. (2004). The Missing Link: The Knowledge Filter and Entrepreneurship in Endogenous Growth. Working paper, Center for Business and Policy Studies.

Acs, Zoltan J. (1992). "Small business economics: A global perspective." Challenge, 35: 38-44, November-December.

Acs, Zoltan J., and A. Varga. (2004). "Entrepreneurship, agglomeration, and technological change." Discussion paper on entrepreneurship, growth, and public policy 0604, Max Plank Institute for Research into Economic Systems, March.

Acs, Zoltan J., and Catherine Armington. (2003). "Endogenous growth and entrepreneurial activity in cities." Research paper 03-02, Center for Economic Studies (CES), U.S. Bureau of the Census, January.

Acs, Zoltan J., and David B. Audretsch. (1987). "Innovation, market structure, and firm size." Review of Economics and Statistics, 69: 567-574.

Acs, Zoltan J., and David B. Audretsch. (1990). Innovation and Small Firms. Cambridge, MA: MIT Press.

Adams, James D., Grant C. Black, J. Roger Clemmons, and Paula E. Stephan. (2005). "Scientific teams and institutional collaborations: Evidence from U.S. universities, 1981-1999." Research Policy, 34(3): 259-285.

Agwara, Hezekiah, Philip Auerswald, and Brian Higginbotham. (2014). "Algorithms and the changing frontier." Working paper 20039, National Bureau of Economic Research (NBER), April.

Appleyard, Melissa M. (2003). "The influence of knowledge accumulation on buyer-supplier co-development projects." The Journal of Product Innovation Management, 20(5): 356-373.

Arthur, W. Brian. (2013). "Complexity economics: A different framework for economic thought." Working paper 2013-04-012, Santa Fe Institute.

Aspen Network of Development Entrepreneurs. (2009). 2009 Impact Report. Washington, DC: The Aspen Institute.

Audretsch, David. (1995). Innovation and Industry Evolution. Cambridge, MA: MIT Press.

Auerswald, Philip. (2008). "Entrepreneurship in the theory of the firm." Small Business Economics, 30(2): 111-126.

Auerswald, Philip. (2010). "Entry and Schumpeterian profits: How technological complexity affects industry evolution." Journal of Evolutionary Economics, 20(4): 553-582.

Auerswald, Philip. (2012). The Coming Prosperity: How Entrepreneurs Are Transforming the Global Economy. New York: Oxford University Press.

Auerswald, Philip, Stuart Kauffman, and José Lobo. (1994). "Diversity, growth, and economic webs." Unpublished manuscript. Accessible at http://papers.ssrn.com/sol3/papers.cfm?abstract_ id $=1460991$. 
Auerswald, Philip, Stuart Kauffman, José Lobo, and Karl Shell. (2000). "The production recipes approach to modeling technological innovation: An application to learning by doing." Journal of Economic Dynamics and Control, 24: 389-450.

Auerswald, Philip, Lewis Branscomb, Sean Gorman, Rajendra Kulkarni, and Laurie Schintler. (2007). Placing Innovation: A Geographical Information Systems (GIS) Approach to Identifying Emergent Technological Activity. Report to the U.S. Department of Commerce, Advanced Technology Program/NIST GCR 06-902, May.

Ayyagari, Meghana, Thorsten Beck, and Asli Demirguc-Kunt. (2003). "Small and medium enterprises across the globe: A new database." Working paper 3127, World Bank Policy Research.

Bairoch, P. (1988). Cities and Economic Development. Chicago: University of Chicago Press.

Baumol, William J. (1990). "Entrepreneurship: Productive, unproductive, and destructive." Journal of Political Economy, 98(5): 893-921.

Baumol, William J., Robert E. Litan, and Carl J. Schramm. (2007). Good Capitalism, Bad Capitalism, and the Economics of Growth and Prosperity. New Haven, CT: Yale University Press.

Bengtsson, Jan, Sven G. Nilsson, Alain Franc, and Paolo Menozzidi. (2000). "Biodiversity, disturbances, ecosystem function and management of European forests." Forest Ecology and Management, 132(1): 39-50.

Berwick, Donald. (2008). "The science of improvement." Journal of the American Medical Association, 299(10): 1182-1184.

Branscomb, Lewis, and Philip E. Auerswald. (2002). Between Invention and Innovation: Mapping the Funding for Early Stage Technology Development. Report to the Advanced Technology Program/ NIST \#NIST GCR 02-841, November.

Burt, Ronald S. (2004). "Structural holes and good ideas." American Journal of Sociology, 110(2): 349-399.

Butler, Patrick, Ted W. Hall, Alistair M. Hanna, Lenny Mendonca, Byron Auguste, James Manyika, and Anupam Sahay. (1997). "A revolution in interaction." McKinsey Quarterly, 1: 4-23.

Cassidy, John. (1998). "Annals of enterprise: The comeback." The New Yorker, February 23, 122-127.

Castilla, Emilio J., Hokyu Hwang, Ellen Granovetter, and Mark Granovetter. (2000). "Social networks in Silicon Valley." In The Silicon Valley Edge, Chong-Moon Lee, William F. Miller, Marguerite Gong Hancock, and Henry S. Rowen, eds. Stanford, CA: Stanford University Press.

Chastain, Erick, Rustom Antia, and Carl Bergstrom (2012), "Defensive Complexity and Antagonistic Coevolution," unpublished manuscript (Cornell University Library), March.

Chatterji, Aaron, Edward Glaeser, and William Kerr. (2013). "Clusters of entrepreneurship and Innovation." Working paper 19013, National Bureau of Economic Research (NBER), May.

Chisholm, John (2013). "How US Entrepreneurship Has Changed Over the Last 20 Years," Presentation at APEE 2013, April.

Coase, Ronald. (1937). "The nature of the firm." Economica, 4: 386-405. 
Coase, Ronald. (1960). "The problem of social cost." Journal of Law and Economics, 3: 1-44.

Competition Commission of Pakistan. (2009). The State of Competition in Pakistan. Islamabad, Pakistan: Competition Commission of Pakistan.

Dean, Thomas J., and Robert L. Brown (1995). "Pollution Regulation as a Barrier to New Firm Entry: Initial Evidence and Implications for Future Research." The Academy of Management Journal 38(1), February: 288-303

Dutz, Michael. (2007). Unleashing India's Innovation: Towards Sustainable and Inclusive Growth. Washington, DC: World Bank.

Dutz, Mark A., Ioannis Kessides, Stephen O'Connell and Robert D. Willig (2011). Competition and Innovation-Driven Inclusive Growth. Washington, DC: The World Bank.

Feld, Brad. (2012). Startup Communities: Building an Entrepreneurial Ecosystem in Your City. New York: Wiley.

Feldman, Maryann P., and David B. Audretsch. (1999). "Innovation in cities: Science-based diversity, specialization, and localized competition." European Economic Review, 43: 409-429.

Flora, Cornelia Butler, and Jan L. Flora. (1993). "Entrepreneurial social infrastructure: A necessary ingredient." Annals of the American Academy of Political and Social Science, 529 (September): 48-58.

Freeman, Richard B., and Wei Huang. (2014). "Collaborating with people like me: Ethnic co-authorship within the U.S." Working paper 19905, National Bureau of Economic Research (NBER), February.

Gavrilets, Sergey. (1999). "A dynamical theory of speciation on holey adaptive landscapes." American Naturalist, 154: 1-22.

Gavrilets, Sergey. (2003). "Models of speciation: What have we learned in 40 years?" Evolution, 57: 2197-2215.

Geertz, Clifford. (1963). Peddlers and Princes: Social Development and Economic Change in Two Indonesian Towns. Chicago: University of Chicago Press.

Glaeser, Edward H., Hedi Kallal, José Scheinkman, and Andrei Shleifer. (1992). "Growth in cities." Journal of Political Economy, 100(6): 1126-1152.

Gleick, James. (2011). The Information: A History, a Theory, a Flood. New York: Pantheon.

Granovetter, Mark. (1973). "Strength of weak ties." American Journal of Sociology, 78: 1360-1380.

Global Entrepreneurship Congress. (2014). "GES policy roundtable summary of discussions." Working paper, Ewing Marion Kauffman Foundation.

Hausmann, Ricardo. (2009). "The other invisible hand: High bandwidth development policy." In What Works in Development? Thinking Big and Thinking Small, Jessica Cohen and William Easterly, eds. Washington, DC: Brookings Institution Press. 
Hausmann, Ricardo, and César A. Hidalgo. (2011). "The network structure of economic output." Journal of Economic Growth, 16: 309-342.

Hausmann, Ricardo, César A. Hidalgo, Sebastian Bustos, Michele Coscia, Sarah Chung, Juan Jimenez, Alex Simoes, and Muhammed Yildirim. (2011). The Atlas of Economic Complexity: Mapping Paths to Prosperity. Available at http://atlas.media.mit.edu/book/.

Helbing, Dirk, and Alan Kirman. (2013). "Rethinking economics using complexity theory." Unpublished manuscript.

Heyes, Anthony (2009). "Is environmental regulation bad for competition? A survey." Journal of Regulatory Economics 36:1-28.

Hidalgo, César A., and Ricardo Hausmann. (2009). "The building blocks of economic complexity." Proceedings of the National Academy of Sciences of the United States of America, 106(26): 10,570-10,575.

Hirschman, Albert O. (1958). The Strategy of Economic Development. New Haven, CT: Yale University Press.

Hirschman, Albert O. (1970). Exit, Voice, and Loyalty: Responses to Decline in Firms, Organizations, and States. Cambridge, MA: Harvard University Press.

Holling, C. S., D. W. Schindler, B. Walker, and J. Roughgarden. (1995). "Biodiversity in the functioning of ecosystems: An ecological primer and synthesis." In Biodiversity Loss: Ecological and Economic Issues, Charles Perrings, Karl Göran Mäler, Carl Folke, C. S. Holling, and Bengt-Owe Jansson, eds. Cambridge, UK: Cambridge University Press.

Huang, Yasheng. (2008). Capitalism with Chinese Characteristics: Entrepreneurship and the State. New York: Cambridge University Press.

Hwang, Victor, and Gregory Horowitt. (2012). The Rainforest: The Secret to Building the Next Silicon Valley. San Jose, CA: Regenwald.

Isenberg, Daniel J. (2010). "How to start an entrepreneurial revolution," Harvard Business Review, 88 (June): $40-50$.

Jacobs, Jane. (1961). The Death and Life of Great American Cities. New York: Random House.

Jacobs, Jane. (1969). The Economy of Cities. New York: Random House.

Jacobs, Jane. (1984). Cities and the Wealth of Nations, Principles of Economic Life. New York: Random House.

Jones, Benjamin F. (2005a). "Age and great invention." Working paper 11359, National Bureau of Economic Research (NBER), May.

Jones, Benjamin F. (2005b). "The burden of knowledge and the 'death of the renaissance man': Is innovation getting harder?" Working paper 11360, National Bureau of Economic Research (NBER), May.

Jones, Benjamin F., E. J. Reedy, and Bruce A. Weinberg. (2014). "Age and scientific genius." Working paper 19866, National Bureau of Economic Research (NBER), January. 
Kash, Don E., and Robert Rycroft. (1999). The Complexity Challenge: Technological Innovation for the 21st Century. London: Pinter.

Kauffman, Stuart. (1988). "The evolution of economic webs." In The Economy as an Evolving Complex System, P. W. Anderson, K. J. Arrow, and D. Pines, eds. New York: Addison Wesley, 125-146.

Kauffman, Stuart. (1993). The Origins of Order: Self-Organization and Selection in Evolution. New York: Oxford University Press.

Kauffman, Stuart, and Simon Levin. (1987). "Towards a general theory of adaptive walks on rugged landscapes." Journal of Theoretical Biology, 128: 11-45.

Kleiner, Morris M., and Alan B. Krueger (2013). "Analyzing the Extent and Influence of Occupational Licensing on the Labor Market." Journal of Labor Economics 31 (April 2): S173-S202.

Kleiner, Morris M., Allison Marier, Kyoung Won Park, and Coady Wing (2014), "Relaxing Occupational Licensing Requirements: Analyzing Wages and Prices for a Medical Service," Working paper 19906, National Bureau of Economic Research (NBER), February.

Kogut, B., and U. Zander. (1992). "Knowledge of the firm, combinative capabilities, and the replication of technology." Organization Science, 3: 383-397.

Leslie, Stuart W. (2000). "The biggest angel of them all: The military and the making of Silicon Valley." In Understanding Silicon Valley: The Anatomy of an Entrepreneurial Region, Martin Kenney, ed. Stanford CA: Stanford University Press, 2000, 48-70.

Lichtenstein, G., T. S. Lyons, and N. Kutzhanova. (2004). "Building entrepreneurial communities: The appropriate role of enterprise development activities." Journal of the Community Development Society, 35(1): 5-24.

Marshak, Jacob, and Roy Radner. (1972). Economic Theory of Teams. New Haven, CT: Yale University Press.

Marshall, Alfred, and John King Whitaker. (1996). The Correspondence of Alfred Marshall, Economist. Cambridge, UK: Cambridge University Press.

Melo, Horatio. (2012). "Prosperity through connectedness." Innovations: Technology, Governance, Globalization, 7(2): 19-23.

McNerney, James. (2013). "The trophic theory of technological improvement." Presentation at the Santa Fe Institute workshop, "Getting Inside the Black Box: Technological Evolution and Economic Growth," August 13.

Michelacci, Claudio. (2003). "Low returns to R\&D due to the lack of entrepreneurial skills." The Economic Journal, 113 (January): 207-225.

Morris, Rhett. (2013). What Do the Best Entrepreneurs Want in a City? Lessons from the Founders of America's Fastest-Growing Companies. New York: Endeavor Insight.

Motoyama, Yasuyuki, Jared Konczal, Jordan Bell-Masterson, and Arnobio Morelix. (2014). "Think locally, act locally: Building a robust entrepreneurial ecosystem." Working paper, Ewing Marion Kauffman Foundation, April. 
Nelson, Richard R., and Sidney G. Winter. (1982). An Evolutionary Theory of Economic Change. Cambridge, MA: Belknap Press.

Olson, Mancur. (1982). The Rise and Decline of Nations: Economic Growth, Stagflation, and Social Rigidities. New Haven, CT: Yale University Press.

Olson, Mancur. (1999). Power and Prosperity: Outgrowing Communist and Capitalist Dictatorships. New York: Basic Books.

Pashigian, P. (1984). "The effects of environmental regulation on optimal plant size and factor shares." Journal of Law and Economics, 27(1): 1-28.

Pentland, Alex. (2014). Social Physics: How Good Ideas Spread-The Lessons from a New Science. New York: Penguin Press.

Porter, Michael. (1998). "Clusters and the new economics of competition." Harvard Business Review, 76(6): 77-90.

Pritchett, L., and J. Sandefur. (2013). "Context matters for size: Why external validity claims and development practice don't mix." Working paper 336, Center for Global Development, Washington, DC.

Quigley, John M. (1998). "Urban diversity and economic growth." Journal of Economic Perspectives, 12(2): 127-138.

Radner, Roy. (1993). "The organization of decentralized information processing." Econometrica, 61(5): 1109-1146.

Rodrik, Dani. (2004). "Industrial policy for the 21st century." Discussion paper 4767, Center for Economic Policy Research (CEPR).

Romer, Paul M. (1986). "Increasing returns and long-run growth." Journal of Political Economy, 94: 1002-1037.

Romer, Paul M. (1990). "Endogenous technological change." Journal of Political Economy, 98(5): S71-S102.

Saxenian, Annalee. (1994). Regional Advantage: Culture and Competition in Silicon Valley and Route 128. Cambridge, MA: Harvard University Press.

Schmitz, J. A., Jr. (1989). "Imitation, entrepreneurship, and long-run growth." Journal of Political Economy, 97: 721-739.

Schumpeter, Joseph A. (1912). Theorie der witschaftlichen Entwicklung. Leipzig: Duncker \& Humblot. Revised English translation (1934) by Redvers Opie, The Theory of Economic Development. Oxford, UK: Oxford University Press.

Simon, Herbert A. (1965). The Shape of Automation for Men and Management. New York: Harper \& Row.

Simon, Herbert A. (1967). "Programs as factors of production." California Management Review, 67(10): 1-12.

Spencer, Herbert. (1857). "Progress: Its law and cause." The Westminster Review, 67: 445-465. 
Srinivasan, T. N. (2004). Annual Bank Conference on Development Economics: Accelerating Development. Washington, DC: World Bank.

Stangler, Dane. (2009). "The economic future just happened." Working paper, Ewing Marion Kauffman Foundation, June.

Starr, Evan, Norman Bishara, and J.J. Prescott (2014), "Noncompetes in the U.S. Labor Force," unpublished manuscript presented at the 2015 Annual Meeting of the American Economic Association.

Tansley, Arthur George. (1935). "The use and abuse of vegetational concepts and terms." Ecology, 16(3): 284-307.

Teece, David J., Gary Pisano, and Amy Shuen. (1997). "Dynamic capabilities and strategic management." Strategic Management Journal, 18(7): 509-533.

van Stel, André, Martin Carree, and Roy Thurik. (2004). "The effect of entrepreneurship on national economic growth: An analysis using the GEM database." Discussion paper on entrepreneurship, growth, and public policy 0604, Max Plank Institute for Research into Economic Systems, April.

Wadhwa, Vivek. (2012). "The magic happens when you focus on people." Innovations: Technology, Governance, Globalization, 7(2): 25-27.

Watts, Duncan J., and Steven H. Strogatz. (1998). "Collective dynamics of 'small-world' networks." Nature, 393(4): 440-442.

Weitzman, Martin L. (1998). "Recombinant growth." Quarterly Journal of Economics, 113(2): 331-360.

Winter, Sidney G. (1968). "Toward a neo-Schumpeterian theory of the firm." Working paper P-3802, RAND, March.

Whittle, Dennis. (2013). "How feedback loops can improve aid (and maybe governance)." Essay, Center for Global Development, August.

Wright, Sewell. (1932). "The roles of mutation, inbreeding, crossbreeding and selection in evolution." Proceedings of the Sixth International Congress of Genetics, 1: 356-366.

World Economic Forum. (2013). Entrepreneurial Ecosystems around the Globe and Company Growth Dynamics: Report Summary for the Annual Meeting of the New Champions 2013. Geneva, Switzerland: World Economic Forum, September.

Zucker, Lynn G., Michael R. Darby, and Jeff Armstrong. (1998). "Geographically localized knowledge: Spillovers or markets?" Economic Inquiry, 36: 65-86. 


\section{ENDNOTES}

1. Tansley (1935), p. 299.

2. Baumol (1990).

3. Baumol, Litan, and Schramm (2009); Baumol (2010); Auerswald (2012).

4. Baumol (1990), p. 893.

5. Acs and Audretsch $(1987,1990)$ and Audretsch (1995) set the stage by providing empirical evidence of the significant role of small firms in generating technological innovations in the United States. Acs (1992) went further to sketch multiple pathways by which entrepreneurial activity drives economic growth. Schmitz (1989) offered a formal model of this process in which the entrepreneur is represented as an imitator of incumbents. Acs and Armington (2003) empirically assessed the role of entrepreneurs in promoting knowledge spillovers and growth at the scale of a city, also focused on the United States. Acs and Varga (2004) and Stel et al. (2004) both employed data from the Global Entrepreneurship Monitor (GEM) project to study the relationship between entrepreneurship and growth at the scale of the nation. Michelacci (2003) and Acs et al. (2004) explored the role of entrepreneurs as knowledge "implementors" or "filters," respectively, and the manner in which those functions drive economic growth. Weitzman (1998) and Michelacci (2003) presented models in which the ultimate limits to growth will lie not in the generation of inventions and new fundamental knowledge that "spills overs" from one part of the economy to another, but rather in the availability of Schumpeterian entrepreneurs to guide the conversion of those inventions and new knowledge into practice through innovation.

6. In 2009, the Aspen Institute launched the Aspen Network of Development Entrepreneurs, which today comprises 190 member institutions that operate a variety of programs intended to support small and growing businesses in 150 countries (ref. http://www.aspeninstitute.org/policy-work/aspennetwork-development-entrepreneurs.) In 2010, the Chilean government launched Startup Chile, a program that aspires to convert Chile into the innovation and entrepreneurship hub of Latin America (Melo 2012; Wadhwa 2012). The U.S. government launched Startup America the following year, and more than a dozen other countries launched national Startup initiatives in the next four years (ref. http://www.startupnations.org/). In 2011, the World Bank established an Innovation, Technology, and Entrepreneurship Practice as one of six global practices of the Finance and Private Sector Development Network. In its review of the World Bank Group's \$18 billion portfolio, the Bank's Independent Evaluation Group articulated a commonly held perspective on the motivation of national and regional programs to support entrepreneurship: "Entrepreneurs serve as agents of change and growth in marketbased economies, providing a major channel through which innovative ideas can be turned into wealth (Srinivasan 2004). Innovation and entrepreneurship can be mutually reinforcing and together can be a powerful source of improved productivity and competitiveness, helping to reduce poverty and stimulate long-term economic growth." (Dutz 2007; World Bank 2010).

7. Isenberg (2010).

8. Feld (2012); Hwang and Horowitt (2012).

9. Auerswald et al. (2007) provide a survey.

10. Relevant context-setting papers include Flora and Flora (1993) and Lichtenstein et al. (2004). 
11. The epistemological substructure (logical positivism) and default analytic techniques (constrained optimization) of neo-classical economics derive from mathematics, rather than from the life sciences.

12. Nelson and Winter (1982); Spencer (1857).

13. Tansley (1935), p. 306. In addition to providing a foundational definition of the term "ecosystem," Tansley's paper offers a starting point for defining progress in regional development (and, by extension, local competitiveness). Changes in vegetation, termed "succession," are analogous to the progressive development of practices within an industry or local economy:

Succession is a continuous process of change in vegetation, which can be separated into a series of phases. When the dominating factors of change depend directly on the activities of the plants themselves (autogenic factors) the succession is autogenic; when the dominating factors are external to the plants (allogenic factors), it is allogenic. The successions (priseres) which lead from bare substrata to the highest types of vegetation actually present in a climatic region (progressive) are primarily autogenic. Those that lead away from these higher forms of vegetation (retrogressive) are largely allogenic, though both types of factors enter into all successions. (Tansley 1935, p. 306.)

Just as succession can be either autogenic or allogenic, the evolution of both industries and entrepreneurial ecosystems can be either endogeneously driven or exogenously driven. Furthermore, just as Tansley defines successions that lead toward greater biological complexity as progressive change in biological systems, so I suggest that the evolution of the capabilities of a city or region toward greater complexity constitutes progressive change in economic systems. Auerswald, Kauffman, and Lobo (1994) formalize this idea. (2013).

14. Arthur (2013) presents a fully elaborated parallel argument. See also Helbing and Kirman

15. Schumpeter (1912).

16. Winter (1968), p. 9.

17. Some time ago, my coauthors Stuart Kauffman, Jose Lobo, Karl Shell, and I described how a formal model of production recipes fits into production theory (Auerswald et al. 2000). This paper built upon Auerswald et al. (1994). Significant precursors are Simon (1967) and Winter (1968). I since have endeavored to connect this model with the Coasean theory of the firm, arguing that the two jointly offer a starting point for understanding entrepreneurship in the theory of the firm (Auerswald 2008) and to derive some of its first-order implications for industrial organization (Auerswald 2010).

18. I do not address speciation in this paper. However, I note that the work of Gavrilets (1999, 2003) provides an interesting starting point for developing formal economic theories based on a modeling in evolutionary biology.

19. Porter (1998), pp. 85-86.

20. Teece et al. (1997)

21. Hidalgo et al. (2009); Hausmann and Hidalgo (2011); Hausmann et al. (2011).

22. Butler et al. (1997).

23. Technically speaking, these profits are "quasi-rents," or returns from the possession of a 
factor of production that is restricted for a limited time period - for example, knowledge of how to produce a particular good or service.

24. Economic complexity can be measured in a number of ways. It can be measured most directly in terms of the number of parts in a technological object. For example, the John Deere tractor sold today is clearly more complex than McCormick's reaper of the 1830s, which in turn was more complex than a plow. More complex objects imply that more complex social arrangements are required to produce the objects; the technical dimensions of complexity (e.g., the number of parts in an object and the intricacy of their assembly) are thus directly linked to the organizational requirements of production.

Focusing on organizational dimensions rather than on the characteristics of objects, complexity also may be understood as the extent to which new market innovations require the efforts of teams that are incorporating multiple distinct fields of inquiry — that is, the average size and/or diversity of teams involved in creating new technological innovations (Kash and Rycroft 1999; Adams et al. 2005)_ or, from a human capital standpoint, the average investment an individual must make to reach the technological frontier. Interpreted in this way, increased complexity will manifest not only in trends to expand the scope of the firm via "combination" and "integration" (as described by Coase 1937) that will be represented in single-firm production recipes, but also in the intricacies of buyer-supplier relationships and peer production networks (Appleyard 2003; Auerswald 2008; Agwara et al. (2014).

Classic works by Simon (1965, 1967); Marshak and Radner (1972); Radner (1993), as well as some more recent papers (Auerswald et al. 2000; Rivkin 2000; Auerswald 2008; Auerswald 2010) have defined more complex problems simply as those for which finding a good solution is more difficult. Notions of computational complexity related to the difficulty of solving a particular problem are at the heart of algorithmic information theory; as such, they can be defined quite formally (specifically, Kolmogorov complexity and NP completeness). As applied to production recipes, the greater the complexity of the technology, the lower the correlation between the effectiveness of the original recipe (i.e., the leader's method) and that of the same recipe altered slightly (i.e., an imperfect imitation). In this work, the complexity of a production recipe is represented by both the number of tasks in the production process and, critically, the degree of interaction among those tasks; in the biological model, these tasks in their most irreducible form correspond to alleles in a gene; interactions among tasks correspond to epistatic interactions among alleles.

This last definition is the one that drives the implications of complexity for both entrepreneurial ecosystems and industry evolution most directly.

\section{Auerswald (2010) provides a proof of this proposition.}

26. "Non-rival" means that one person's use of an idea does not keep another person from using the idea; "non-excludable" means that it is impossible to keep a person from using an idea once it is "out in the open;" and "knowledge" refers to the costless transmission of ideas that are non-rival and non-excludable. Romer actually uses the term "recipes" to refer to useful productive knowledge, as Karl Shell, Stuart Kauffman, José Lobo, and I have independently.

27. To emphasize: the focus here is not on web pages and pirated music videos. These digitized products - even including patents—are not the same thing as production recipes.

28. Romer (1986, 1990). See also Zucker et al. (1998). There is no disputing that ideas created by one person, or within one firm, can reach other people or firms through multiple pathways, many of which do not involve direct compensation of the innovator by the beneficiary. If one chooses to refer to such pathways as "knowledge spillovers," then such spillovers will be in evidence everywhere. Yet, when such pathways involve economic benefit derived from entrepreneurship, in most cases they 
also involve significant costs: recruiting a key employee from a competitor firm or industry leader; undertaking research to invent around a patent; reverse engineering a product; paying for employee attendance at conferences; hiring consultants; building a trusted relationship with a buyer or supplier. Furthermore, to the extent that the public benefits not captured by the entrepreneur (resulting from "knowledge spillovers" or other mechanisms) are temporally far off or uncertain, it is unlikely that they will be of greater importance to entrepreneurial decision making than will be the immediate, first-order challenges of defining a viable business model; building a team to execute; testing an initial product or service; finding customers or otherwise financing the firm's launch; marketing the product or service and adapting to market response; managing growth and expansion; and otherwise organizing the firm's operations.

\section{Burt (2004, p. 351 [footnote 2]).}

30. Parts of this section derive from Auerswald et al. (2007).

31. As Coase (1937, p. 397) famously argued, introducing transaction costs into an otherwise perfectly competitive market framework is sufficient to motivate the existence of firms: There is a combination when transactions which were previously organized by two or more entrepreneurs become organized by one. This becomes integration when it involves the organization of transactions which were previously carried out between the entrepreneurs on a market. A firm can expand in either or both of these ways.

32. I elaborate on the relationship between Coasean and Schumpeterian theories of the firm in Auerswald (2008).

33. Burt (2004, p. 351 [footnote 2]). See also Pentland (2014); Freeman and Huang (2014).

34. For formal development of the analogy in evolutionary biology, see Gavrilets (1999).

35. Hidalgo and Hausmann (2009), p. 10,575.

36. Tansley (1935); Hausmann, Hidalgo, and co-authors use the term "capabilities" rather than production recipes. While they do not explicitly model those capabilities, the meaning is essentially analogous. See also McNerney (2013).

37. See also Bairoch (1988).

38. Saxenian (1994), p. 57.

39. As Saxenian stated in a 1998 interview comparing technology development in Silicon Valley with film production in Los Angeles, "You have these very fluid labor markets and these communities of highly skilled people who recombine repeatedly. They come together for one project-in this case a new film, in Silicon Valley it would be a new firm-and then they move on. The system allows a lot of flexibility and adaptiveness ... Information about new markets and new technologies flows very quickly. This sustains the importance of geographic proximity, despite the fact that, theoretically, the technology allows you to be anywhere" (Cassidy 1998), p. 125.

40. Granovetter (1973); see also work by Watts and Strogatz (1998) and others on "small world" networks. The success of each of these institutional types depends on the existence of others, including not only well-recognized entities such as venture capital firms, large corporations, and universities, but also angel networks, university and corporate venture capital funds and incubators, experimental R\&D programs supported by federal and state government, fast-track regulatory clearance services by state and local governments, and specialized services firms (e.g., in law, real estate, or accounting). Auerswald 
and Branscomb (2002) refer to the efforts to convert new knowledge into commercial innovations in such a context as "collective entrepreneurship," addressing the balance, typically required for success, of collaboration between different types of people and of individual vision.

41. Olson (1999), pp. 188-189. This single quote stands in for a deeply considered argument, fully presented in Power and Prosperity, on which the material in this section rests, but which (for obvious reasons) I will not summarize here.

42. Competition Commission of Pakistan (2009) provides a case study.

43. Olson (1999), pp. 188-189.

44. Hirschman (1958), p. 5.

45. Hirschman (1970).

46. Auerswald (2012).

47. Global Entrepreneurship Congress (2014).

48. Geertz (1963), p. 28.

49. Ayyagari et al. (2003).

50. Olson (1999).

51. Morris (2013).

52. World Economic Forum (2013).

53. Sutton (1991).

54. This domain is directly analogous to the area of non-tariff barriers to trade in trade theory.

55. Dean and Brown (1995, p. 292) offer this description: "The effect of complexity on new firm entry can be understood through the concept of the learning curve ... The more a firm deals with environmental regulatory agencies and has to perform pollution control activities, the more the firm learns (1) which regulations and agencies apply to its activities and how effectively to handle them, (2) which pollution abatement technologies and how to use them effectively, and (3) how to best modify its organizational and administrative processes to carry out these tasks. In other words, compliance learning translates into lower per-unit compliance costs for incumbents (Monty 1991), so inhibiting new firm entry." Cited in Heyes (2009), p. 13.

56. See. e.g., the review by Heyes (2009); also Pashigian (1984), and Dean and Brown (1995).

57. Personal correspondence. Also Chisholm (2013). Chisholm conjectures that long-term shifts of entrepreneurial activity in the U.S. economy away from the physical production and delivery of goods and services ("atoms") and toward software in various forms ("bits") has been driven to a significant extent on markedly increasing regulatory complexity in atoms-based businesses. A similar phenomenon is even more pronounced in international cross sections; India, Pakistan, and Nigeria, for example, are places where entrepreneurial energies have over the past two decades been overwhelmingly dedicated to bits-based businesses. 
58. Of course, there is a significant difference between the "control system" in the biological case and the "regulator" in an economic context: we generally presume that the "regulator" is a conscious decision maker, whereas the control system in a biological system is not. The work by Chastain et al. suggests that it is not the malevolence of the regulator but rather the regulatory function itself (combined with the process of co-evolution) that is primarily responsible for observed stasis in highly competitive market environments.

59. Rodrik (2004), pp. 2-3.

60. Motoyama et al. (2014), p. 13.

61. I thank Michael Edson for emphasizing to me the importance of this particular formulation for success at scale in complex institutional and social contexts.

62. From 1951 to 1953 , California received $\$ 13$ billion in prime defense contracts, overtaking New York as the leading recipient of defense funding. That surge abated with cuts initiated by Wilson. See Leslie (2000).

63. For the San Diego Story, see Walshok (2013). She observes that "San Diego's transformative journey began early in the 1980s, when the entire Southwest was dealing with the implosion of the savings and loan industry, which resulted in bankruptcies and an overall decline in the powerful building and real estate financing industries, both of which had been major drivers of regional prosperity since the 1950s. This crisis was paralleled by a significant decline in defense manufacturing; in San Diego, this included the aerospace industry and the Atlas missile. In fact, General Dynamics, whose workforce in the San Diego area at one time numbered 60,000, completely closed down over an eighteen-month period, leaving thousands of engineers, technicians, and other workers without jobs by the late 1980s."

64. Stangler (2009).

65. Huang (2008).

66. Berwick (2008), p. 1153.

67. Hausmann (2009), p. 193.

68. Berwick (2008), p. 1153.

69. Alfred Marshall and John King Whitaker (1996), p. 283.

The quote is from a letter written by Alfred Marshall in 1911. The "Tatas" in question are the sons of Jamsetji Tata, the Indian entrepreneur whose ventures turned into a now-global business empire that has spanned generations. This sentence provides evidence that appreciation in the field of economics of the profound role entrepreneurship plays in economic development is neither new nor confined to the work of Joseph Schumpeter. Yet Marshall's formal contributions to economics-and those of the marginalists who followed him-did little to advance understanding of the complex dynamics alluded to in the simple sentence above.

Marshall was the author of Principles of Economics, one of the foundational works in the field of economics. 
E Norts 
$(2)$

(1)

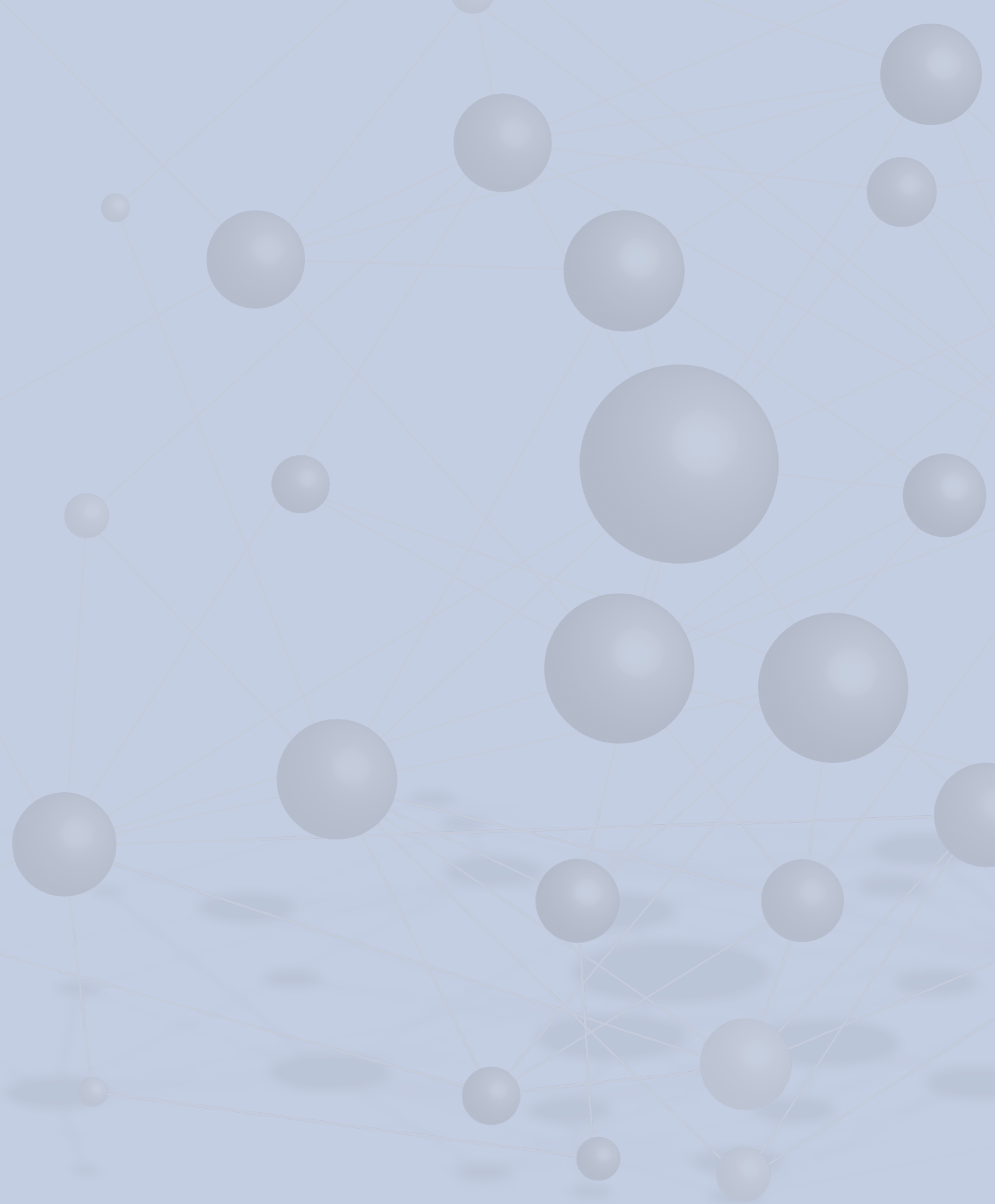




\section{Exwrys Marion \\ KAUFFMAN Foundation \\ Fostering \\ economic independence \\ by advancing \\ education and entrepreneurship}

4801 ROCKHILL ROAD

KANSAS CITY, MISSOURI 64110

816-932-1000

www.kauffman.org 